Note

\title{
Distribution of cadmium in a cultivated soil in Britanny, France
}

\author{
Gisele Mara Hadlich ${ }^{1 *}$; José Martin Ucha² \\ ${ }^{1} U F B A / I G E O$ - Depto. de Geoquímica, R. Barão Geremoabo, s/n - 40170-290 - Salvador, BA - Brasil. \\ 2IF-BAHIA - Depto. de Ciências Aplicadas, R. Emídio dos Santos, s/n - 40301-015 - Salvador, BA - Brasil. \\ *Corresponding author <gisele@ufba.br>
}

\begin{abstract}
Cadmium (Cd) can be potentially toxic to the environment, and its bioavailability is related to the chemical forms it occurs in the soils. The distribution of $\mathrm{Cd}$ into the solid phase and its availability was investigated in a cultivated soil in Britanny, France. Cd sequential extraction was performed using a modified Tessier's sequential extraction protocol. Total content of $\mathrm{Cd}\left(\mathrm{n}=22\right.$ samples) ranged from 0.13 to $0.37 \mathrm{mg} \mathrm{kg}^{-1}$. Long term history of organic and mineral fertilizers application increased $\mathrm{Cd}$ concentration in the surface horizon. The fate of $\mathrm{Cd}$ was correlated with soil available $\mathrm{P}_{2} \mathrm{O}_{5}$ concentration and $\mathrm{pH}$. The regression analysis (linear and non-linear) and Principal Component Analysis revealed the synergistic effect of $\mathrm{P}_{2} \mathrm{O}_{5}$ in the retention of $\mathrm{Cd}$ in cultivated soils. The following fractions' sequence was observed: bounded to $\mathrm{Fe}$ and $\mathrm{Al}$ oxides + phosphates $>$ exchangeable $>$ bound to organic matter $\approx$ residual fraction.
\end{abstract}

Key words: Cd, soil pollution, Tessier protocol, sequencial extraction

\section{Distribuição de cádmio em solo cultivado na Bretanha, França}

\begin{abstract}
RESUMO: O cádmio (Cd) pode ser tóxico no ambiente e sua biodisponibilidade está relacionada às formas químicas em que os metais se encontram no solo. Apresenta-se a distribuição deste metal na fase sólida de um solo cultivado na Bretanha, França, assim como fatores que influenciam sua disponibilidade. Foi realizada a extração sequencial do Cd utilizando o método Tessier, modificado. A concentração total de Cd, avaliada em 22 amostras, variou de 0,13 a $0,37 \mathrm{mg} \mathrm{kg}^{-1}$. O uso contínuo de fertilizantes orgânicos e minerais aumentou a concentração de $\mathrm{Cd}$ no horizonte superficial do solo. A distribuição do $\mathrm{Cd}$ foi relacionada à concentração de $\mathrm{P}_{2} \mathrm{O}_{5}$ disponível e ao pH. Análises de regressão (linear e não linear) e a Análise de Componentes Principais mostraram efeito sinérgico do $\mathrm{P}_{2} \mathrm{O}_{5}$ na retenção de $\mathrm{Cd}$ nos solos cultivados. $\mathrm{O}$ fracionamento apresentou a seguinte sequência: ligado a óxidos de $\mathrm{Fe}$ e de $\mathrm{Al}+$ fosfatos $>$ trocável $>$ ligado à matéria orgânica $\approx$ residual. Palavras-chave: $\mathrm{Cd}$, poluição do solo, método Tessier, extração sequencial
\end{abstract}

\section{Introduction}

Trace metals, as $\mathrm{Cd}$, are potentially toxic to the environment, and their behavior is related to the chemical associations that occur in soils. Thus, the mobility and bioavailability of the metals depend strongly on the physical and chemical properties of the soils. Trace metals can be associated with soil fractions: the exchangeable fraction, considered quickly available; the fraction bound to carbonates, susceptible to changes of $\mathrm{pH}$ in soil; the fraction associated to iron and manganese oxides, thermodynamically unstable under anoxic conditions; the organic matter fraction, that can be degraded, leading to a release of soluble trace metals; the residual fraction that is not available by oxy-reduction reactions or solubilization, and presents fewer environmental risks (Tessier et al., 1979).

In agricultural areas, $\mathrm{Cd}$ accumulates in soils due to application of mineral (mainly phosphates) and organic fertilizers (Campos et al., 2005; Bizarro et al., 2008; Raven and Loeppert, 1997; Levasseur, 2002). Cd may be uptaked by crops or transported to waters. Cd transport from agricultural areas occurs mainly in acidic soils (Mortvedt and Osborn, 1982; Mendes et al., 2006; Reuss et al., 1978).
Lime application is an important management practice to immobilize trace metals because it increases the $\mathrm{pH}$ and favors the adsorption of the metals over the oxides and carbonates surface. Lime may also reduce the $\mathrm{Cd}$ exchangeable fraction and increase the fractions bound to organic matter and oxides, and residual fractions (Melo et al., 2008; Silveira et al., 2008; Matos et al., 1996). The percent of clay, surface area, and percentage of iron oxides were used to predict the amount of $\mathrm{Cd}$ sorbed in the soil (Korte et al., 1976).

The concentration of total $\mathrm{Cd}$ in surface soil amended with phosphates can be highly correlated to total phosphorus concentration (Mulla et al., 1980). The addition of phosphates reduces $\mathrm{Cd}$ availability (Pierangelli et al., 2004; Abou-Zied, 2007; Campbell et al., 2006). The Cd association with the solid phase of soil occurs mainly through cation exchange reactions or specific adsorption. The dominance of the exchangeable and bound to organic matter fractions in surface horizons is due to the negative charges than in the subsurface horizon (Gomes et al., 1997). In subsurface horizons exhibiting low organic matter concentrations, Cd fractions are primarily associated with oxides and residual fractions. 
Assuming that much soil geochemical properties and agricultural practices can modify the trace metal behavior and affect their availability, the aim of the study was to determine soil $\mathrm{Cd}$ concentration and distribution into the solid phase in surface and subsurface horizons of a cultivated soil.

\section{Material and Methods}

The research was developed with soil samples collected in the west of Brittany, France (Figure 1), a region dominated by intense agriculture and cattle farm operations. The Typic Hapludalf soil in this study represents the typical soil type of the region, with a loamy cover and schist substrate (Curmi and Widiatmaka, 1995). Samples were collected along a linear toposequence located in a cultivated area in Ploudiry. The area consisted of 8 ha receiving long-term (over 20 years) repeated applications of pig slurry and high rates of mineral fertilizers. The studied toposequence, with $270 \mathrm{~m}$ and $6 \%$ slope, begins on the top of the hill slope ( $48^{\circ} 28^{\prime} 9.08^{\prime \prime} \mathrm{N}, 4^{\circ} 6^{\prime} 34.64^{\prime \prime} \mathrm{W}$; Figure 1) and finalized at the end of the cultivated area in the middle/ end slope (48²8'10.5" N, 46'45.57" W).

Twenty-two samples, distributed on 11 points (separated by $25-30 \mathrm{~m}$ ), were collected from two continuous horizons identified in the field: the tilled top soil horizon, denominated SH (surface plowed horizon, $0-35 \mathrm{~cm}$, 11 samples), and the subsurface horizon denominated DH ("deep" horizon, under the plowed horizon, 35-50 $\mathrm{cm}, 11$ samples) (Figure 2). The samples were collected with a dutch auger and the outside parts of each sample, in contact with the metal, were rejected. The samples, each one with about $0.5 \mathrm{~kg}$, were disposed in recipients previously decontaminated with $\mathrm{HCl} 10 \%$, at a $4^{\circ} \mathrm{C}$. The samples were dried at $105^{\circ} \mathrm{C}$ in a forced air oven. Cadmium fractionation was performed according to a modified Tessier's protocol (Table 1). This method (Tessier et al., 1979) is largely used to fractioning metals in soils (Rao et al., 2008) and was validated by other authors (Frentiu et al., 2008).
Separations were performed by centrifuging $(3,000$ $\mathrm{rpm}$ ) for $30 \mathrm{~min}$ and the supernatant was analyzed for $\mathrm{Cd}$. The residue was washed with $50 \mathrm{~mL}$ of ultrapure water and this supernatant was discarded. All glassware used for the extractions was previously soaked in $14 \%$ $\mathrm{HNO}_{3}(\mathrm{v} / \mathrm{v})$ and rinsed with ultrapure water. The extracts were analyzed using a graphite furnace atomic ab-

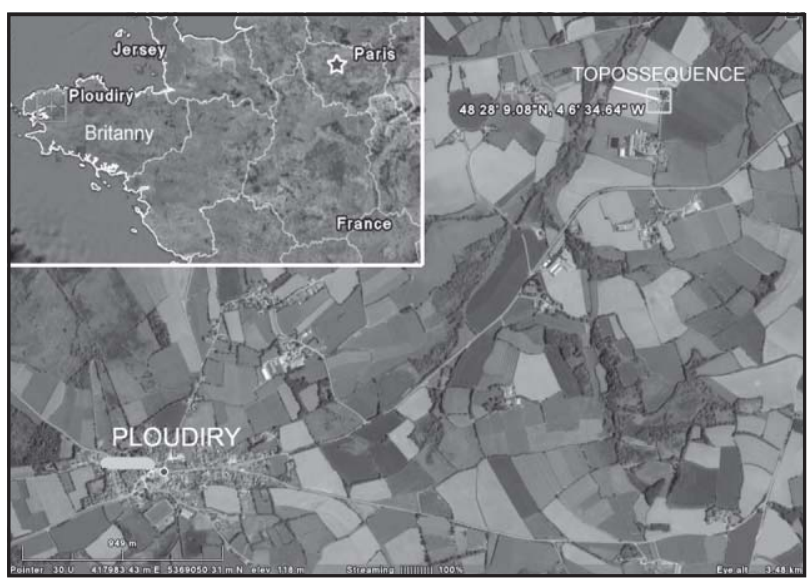

Figure 1 - Location of the toposequence studied in the west of Brittany, France. Source: image obtained from Google Earth ${ }^{\mathrm{TM}}$ (earth.google.com), modified (Accessed Febr. 26, 2010).

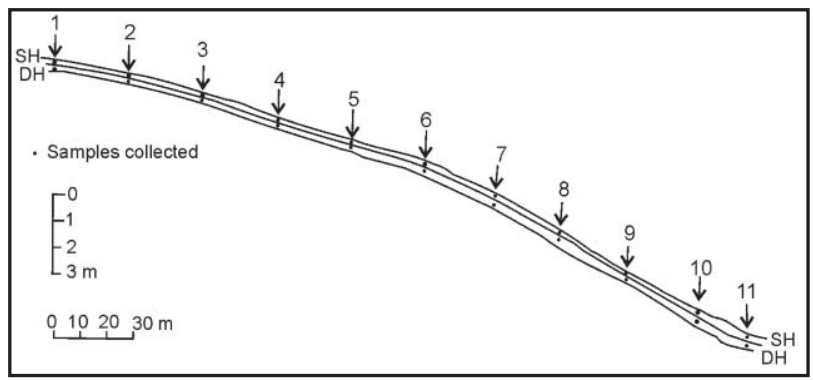

Figure 2 - Profile of the toposequence studied and location of the samples collected.

Table 1 - Protocol adopted for Cd fractioning in soil.

\begin{tabular}{|c|c|c|c|c|}
\hline FRACTION & (1)*exchangeable $(\mathrm{EXCH})$ & $\begin{array}{l}\text { (2)*Fe and Mn } \\
\text { oxides(OXID) }\end{array}$ & $(3)$ *organic matter $(\mathrm{OM})$ & $(4) * *$ residual $(\mathrm{RES})$ \\
\hline Sample & $6.5 \mathrm{~g}$ dry soil & residue of (1) & residue of (2) & residue of (3) \\
\hline $\begin{array}{l}\text { Reagents and } \\
\text { conditions of } \\
\text { the } \\
\text { extraction }\end{array}$ & $\begin{array}{c}50 \mathrm{~mL} \mathrm{MgCl} \\
1 \mathrm{M}(\mathrm{pH} 7), \\
1 \mathrm{~h} \text {, room temperature } \\
\text { continuous shaking }\end{array}$ & $\begin{array}{c}125 \mathrm{~mL} \\
0.04 \mathrm{M} \\
\mathrm{NH}_{2} \mathrm{OH} . \mathrm{HCl} \\
\text { solution } 25 \% \\
\mathrm{CH}_{3} \mathrm{COOH} \\
6 \mathrm{~h}, 96 \pm 4^{\circ} \mathrm{C} \\
\text { periodic shaking }\end{array}$ & $\begin{array}{c}6 \mathrm{~mL} 0.02 \mathrm{M} \mathrm{HNO}_{3}+31.25 \mathrm{~mL} \\
\mathrm{H}_{2} \mathrm{O}_{2}, 2 \mathrm{~h}, 85 \pm 3^{\circ} \mathrm{C} \text {, periodic } \\
\text { shaking, } 18 \mathrm{~mL} \mathrm{H}_{2} \mathrm{O}_{2} 30 \%, 85 \pm \\
3^{\circ} \mathrm{C}, 3 \mathrm{~h} \text {, periodic shaking. After } \\
\text { attain room temperature: } 31 \mathrm{~mL} \\
\mathrm{CH}_{3} \mathrm{COONH} \mathrm{H}_{4} \text { in solution } \\
20 \% \mathrm{HNO}_{3} \text { - dilut the sample to } 100 \\
\mathrm{~mL} \text { with ultra-pure water, } 30 \mathrm{~min}, \\
\text { room temperature, continuous } \\
\text { shaking }\end{array}$ & $\begin{array}{c}\text { dry mineralization } \\
\text { after calcinations } \\
\text { at } 450^{\circ} \mathrm{C} \text {; ash } \\
\text { dissolved with } \\
\mathrm{HCl}\end{array}$ \\
\hline
\end{tabular}


sorption spectrometer (GFAAS) with Zeeman correction, wavelength $228.8 \mathrm{~nm}$ for the $\mathrm{Cd}$ and detection limit $0.01 \mathrm{mg} \mathrm{kg}^{-1}$. The carbonate fraction was not analyzed as a specific fraction (as advocated by the Tessier's protocol) due to the acidic character of the soil. This procedure was suggested by Matos et al. (1996) for acidic soils. Since $\mathrm{Cd}$ was under the detection limit in the used reagents, no blank correction was necessary. In five samples, the total and the available $\mathrm{P}_{2} \mathrm{O}_{5}$ were analyzed before and after the oxides extraction (metals bounded to $\mathrm{Fe}$ and $\mathrm{Mn}$ oxides, fraction 2). As phosphates were dissolved in this fraction, the metals associated to the phosphates were released to the extracted solution of fraction 2.

Other analysis performed: granulometry; $\mathrm{pH}$ (water and $\mathrm{KCl}$ ); organic matter - O.M. (organic carbon Anne); cations exchange capacity - CEC; available phosphates - $\mathrm{P}_{2} \mathrm{O}_{5}$ (Dyer) and free iron - Fe-free (Méhra-Jackson). The analytical methods are described in Baize (2000 a).

Statistical analyses (Principal Component Analysis and regression analysis, using the software Statistica 5.0) were conducted to evaluate the distribution of $\mathrm{Cd}$ in the soil horizons.

\section{Results and Discussion}

Surface and subsurface soil samples exhibited different concentrations of O.M., $\mathrm{P}_{2} \mathrm{O}_{5}$ and CEC (Table 2). The $\mathrm{P}_{2} \mathrm{O}_{5}$ concentration in $\mathrm{SH}$ was greater than in $\mathrm{DH}$. The phosphate increasing into the surface horizon due to the organic and mineral fertilization in the top of the soils, associated to the low mobility of the phosphate applied, are reported by many authors (Hountin et al.,
1997; Gomes et al., 1997; Berwanger et al., 2008). Highest values of CEC in the $\mathrm{SH}$ are certainly related to the highest O.M. and clay concentrations. The $\mathrm{pH}$ and $\mathrm{Fe}$ concentrations are not different between the two horizons.

The values of $\mathrm{Cd}$ in the fractions ranged of 0.01 to $0.21 \mathrm{mg} \mathrm{kg}^{-1}$. The mean values of the fractions also suggested the difference between the horizons. Lower total $\mathrm{Cd}$ concentration was found in the deep horizon (DH), and the mean is comparable to the mean obtained in non cultivated soils in France: $0.16 \mathrm{mg} \mathrm{kg}^{-1}$ (Baize, $2000 \mathrm{~b}$ ). Results indicate no $\mathrm{Cd}$ contamination in the subsurface horizon.

There was no difference in the Cd-res fraction between the horizons. This result indicates no anthropogenic contribution to the residual fraction. On this way, no difference was found in the $\mathrm{Cd}-\mathrm{OM}$ fraction suggesting a low $\mathrm{Cd}$ retention by organic matter. Other metals, as $\mathrm{Cu}$ and $\mathrm{Zn}$, are more retained by de organic matter than Cd (Bertoncini and Mattiazzo, 1999). The proportional fractions of $\mathrm{Cd}$ show that in the both horizons predominates $\mathrm{Cd}$ bound to $\mathrm{Fe}$ and $\mathrm{Mn}$ oxides. This fraction includes the $\mathrm{Cd}$ bounded to the phosphates.

There was no relation between the granulometry fractions, free-Fe and $\mathrm{pH}$ (water) with other physicochemical parameters or with the Cd fractions in the cultivated area (SH and $\mathrm{DH})(p<0.01)$. A positive correlation between O.M. and CEC was found in both sample groups ( $p<0.05$; $\mathrm{SH}:+0.83$; DH: +0.98 ).

These observations contributed to the selection of the parameters for the Principal Component Analysis PCA (Figure 3). The PCA reduces the number of vari-

Table 2 - Mean values and Standard Deviation of the parameters analyzed into the samples of two horizons (SH - surface horizon; DP - deep horizon). Means with different letters in the same lines differ $(p<0.01$. T-test).

\begin{tabular}{|c|c|c|c|c|}
\hline \multirow{2}{*}{ Parameter } & \multicolumn{2}{|c|}{$\mathrm{SH}(\mathrm{n}=10)$} & \multicolumn{2}{|c|}{ DH $(\mathrm{n}=11)$} \\
\hline & mean & S.D. & Mean & S.D. \\
\hline sand $\left(\mathrm{g} \mathrm{kg}^{-1}\right)$ & $227^{\mathrm{NS}}$ & 37 & 271 & 94 \\
\hline silt $\left(\mathrm{g} \mathrm{kg}^{-1}\right)$ & $612^{\mathrm{NS}}$ & 39 & 621 & 112 \\
\hline clay $\left(\mathrm{g} \mathrm{kg}^{-1}\right)$ & $161^{\mathrm{a}}$ & 15 & $108^{\mathrm{b}}$ & 36 \\
\hline $\mathrm{pH}$ (in water) & $6.24^{\mathrm{NS}}$ & 1.51 & 6.06 & 0.69 \\
\hline $\mathrm{pH}$ (in $\mathrm{KCl}$ ) & $5.47^{\mathrm{NS}}$ & 0.54 & 5.10 & 0.51 \\
\hline O.M. (\%) & $3.36^{\mathrm{a}}$ & 0.38 & $1.41^{\mathrm{b}}$ & 0.62 \\
\hline $\mathrm{P} 2 \mathrm{O} 5\left(\mathrm{mg} \mathrm{kg}^{-1}\right)$ & $815^{a}$ & 610 & $83^{b}$ & 73 \\
\hline CEC (meq kg-1) & $113^{a}$ & 11 & $63^{\mathrm{b}}$ & 15 \\
\hline $\mathrm{Fe}(\%)$ & $1.435^{\mathrm{NS}}$ & 0.061 & 1.316 & 0.200 \\
\hline Cd-exch (mg kg- $\left.{ }^{-1}\right)$ & $0.085^{a}(27 \%)$ & 0.032 & $0.040^{\mathrm{b}}(21 \%)$ & 0.031 \\
\hline Cd-oxid (mg kg $\left.{ }^{-1}\right)$ & $0.166^{a}(53 \%)$ & 0.042 & $0.090^{\mathrm{b}}(47 \%)$ & 0.045 \\
\hline Cd-OM (mg kg-1) & $0.037^{\mathrm{NS}}(12 \%)$ & 0.016 & $0.031(16 \%)$ & 0.022 \\
\hline Cd-res $\left(\mathrm{mg} \mathrm{kg}^{-1}\right)$ & $0.026^{\mathrm{NS}}(8 \%)$ & 0.008 & $0.032(16 \%)$ & 0.031 \\
\hline Cd-total (mg kg-1) & $0.314^{a}(100 \%)$ & 0.074 & $0.193^{b}(100 \%)$ & 0.080 \\
\hline
\end{tabular}

Sci. Agric. (Piracicaba, Braz.), v.67, n.6, p.731-736, November/December 2010 


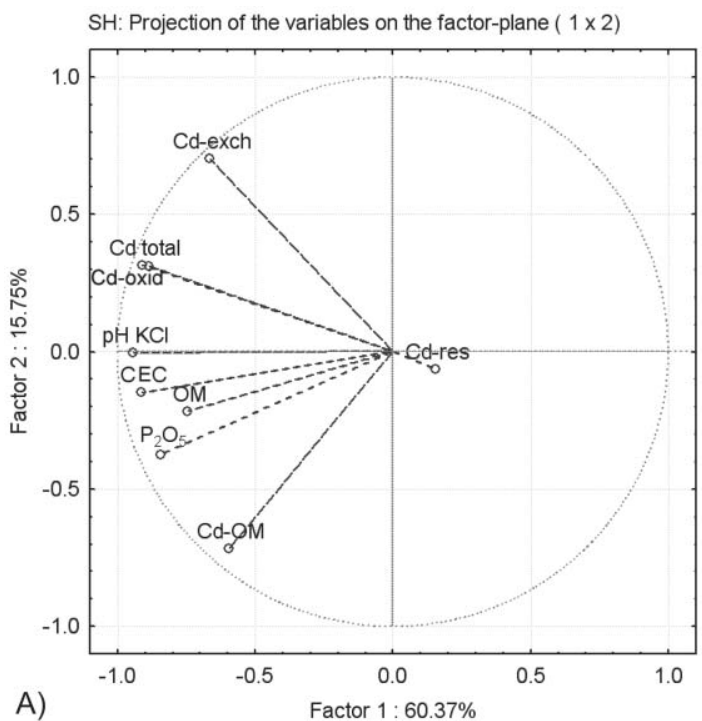

\begin{tabular}{|c|c|c|}
\hline \multicolumn{3}{|c|}{ Variable contributions - Include condition: local= "SH" } \\
\hline & Factor 1 & Factor 2 \\
\hline $\mathrm{pH} \mathrm{KCl}$ & 0.163803 & 0.000014 \\
\hline $\mathrm{OM}$ & 0.102235 & 0.032948 \\
\hline $\mathrm{P}_{2} \mathrm{O}_{5}$ & 0.130694 & 0.098525 \\
\hline $\mathrm{CEC}$ & 0.153684 & 0.015557 \\
\hline Cd-exch & 0.081597 & 0.34855 \\
\hline Cd-oxid & 0.145105 & 0.068691 \\
\hline Cd-OM & 0.065393 & 0.362425 \\
\hline Cd-res & 0.004334 & 0.002743 \\
\hline Cd-total & 0.153156 & 0.070540 \\
\hline
\end{tabular}

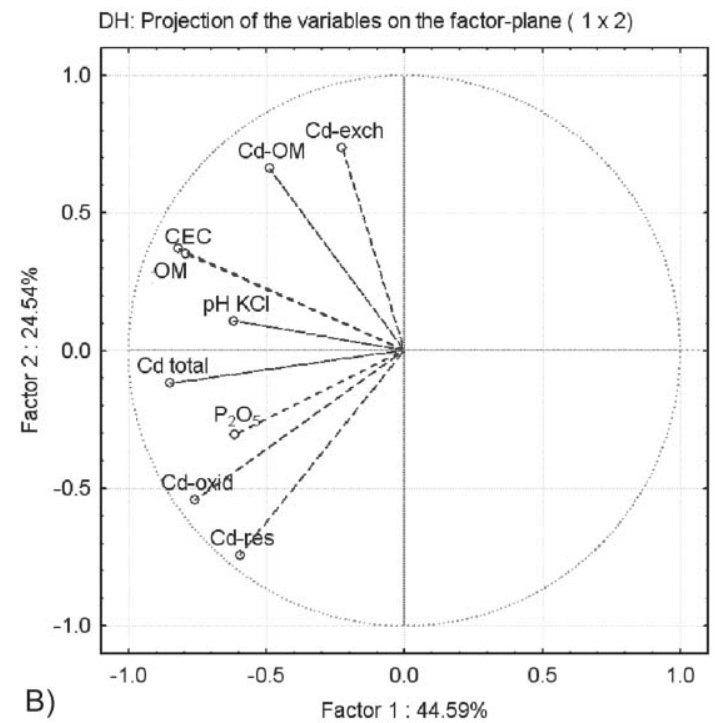

\begin{tabular}{|c|c|c|}
\hline \multicolumn{3}{|c|}{ Variable contributions - Include condition: local= "SH" } \\
\hline & Factor 1 & Factor 2 \\
\hline $\mathrm{pH} \mathrm{KCl}$ & 0.095565 & 0.005399 \\
\hline $\mathrm{OM}$ & 0.167242 & 0.062232 \\
\hline $\mathrm{P}_{2} \mathrm{O}_{5}$ & 0.094314 & 0.041580 \\
\hline $\mathrm{CEC}$ & 0.156951 & 0.056213 \\
\hline Cd-exch & 0.012862 & 0.246255 \\
\hline Cd-oxid & 0.144328 & 0.133689 \\
\hline Cd-OM & 0.059947 & 0.198409 \\
\hline Cd-res & 0.088518 & 0.249908 \\
\hline Cd-total & 0.180275 & 0.006315 \\
\hline
\end{tabular}

Figure 3 - Principal Component Analysis diagrams for variables and their contribution for the first two axes. (A) SH - surface horizon; (B) DH - deep horizon.

ables from the original data to some factors (or principal components) and indicates groups of data that present similar behavior. The two principal components selected are able to account for $69 \%$ of the total variance presented. In the $\mathrm{SH}$ (Figure $3 \mathrm{~A})$, the soil parameters selected ( $\mathrm{pH} \mathrm{KCl}, \mathrm{O} . \mathrm{M} ., \mathrm{P}_{2} \mathrm{O}_{5}$ and $\mathrm{CEC}$ ) and $\mathrm{Cd}-$ oxid and Cd-total concentrations define $60 \%$ of the variance of the data indicated by the first factor. In the $\mathrm{DH}$ (Figure 3B), however, the $\mathrm{P}_{2} \mathrm{O}_{5}$ concentration and the $\mathrm{pH}$ have no significant contributions. The data variance may be better explained by the O.M. content and CEC. In addition, the Cd-oxid and Cd-total data have also a notable contribution in the Factor 1.

The $\mathrm{pH}$ around 6 in the cultivated area and the presence of $\mathrm{Cd}$ associated to the phosphates originated from mineral and organic fertilizers, explain the great proportion of Cd-oxid in the $\mathrm{SH}$ compared to the subsurface horizon. The importance of the $\mathrm{Fe}$ and $\mathrm{Al}$ oxides in the retention of the trace metals by specific adsorption or co-precipitation mechanisms was shown by Gomes et al. (1997).

Pierangeli et al. (2004) showed that the presence of phosphates in soils contributes to reduce $\mathrm{Cd}$ bioavailability. These authors also indicated that other trace metals $(\mathrm{Cu}$ and $\mathrm{Pb})$ are preferably sorbed by the soil compared to $\mathrm{Cd}$. On the other hand, repeated pig slurry application in the cultivated area may have saturated the phosphate adsorption sites in the soil, which also promoted phosphorus desorption (Berwanger et al., 2008). Thus, the Cd bounded to the phosphates may be transported to other environments as lowlands or rivers.

Bertoncini and Mattiazzo (1999) observed the potential for $\mathrm{Cd}$ to be lost with the percolation of soluble organic-metal complexes. The authors presented the fol- 

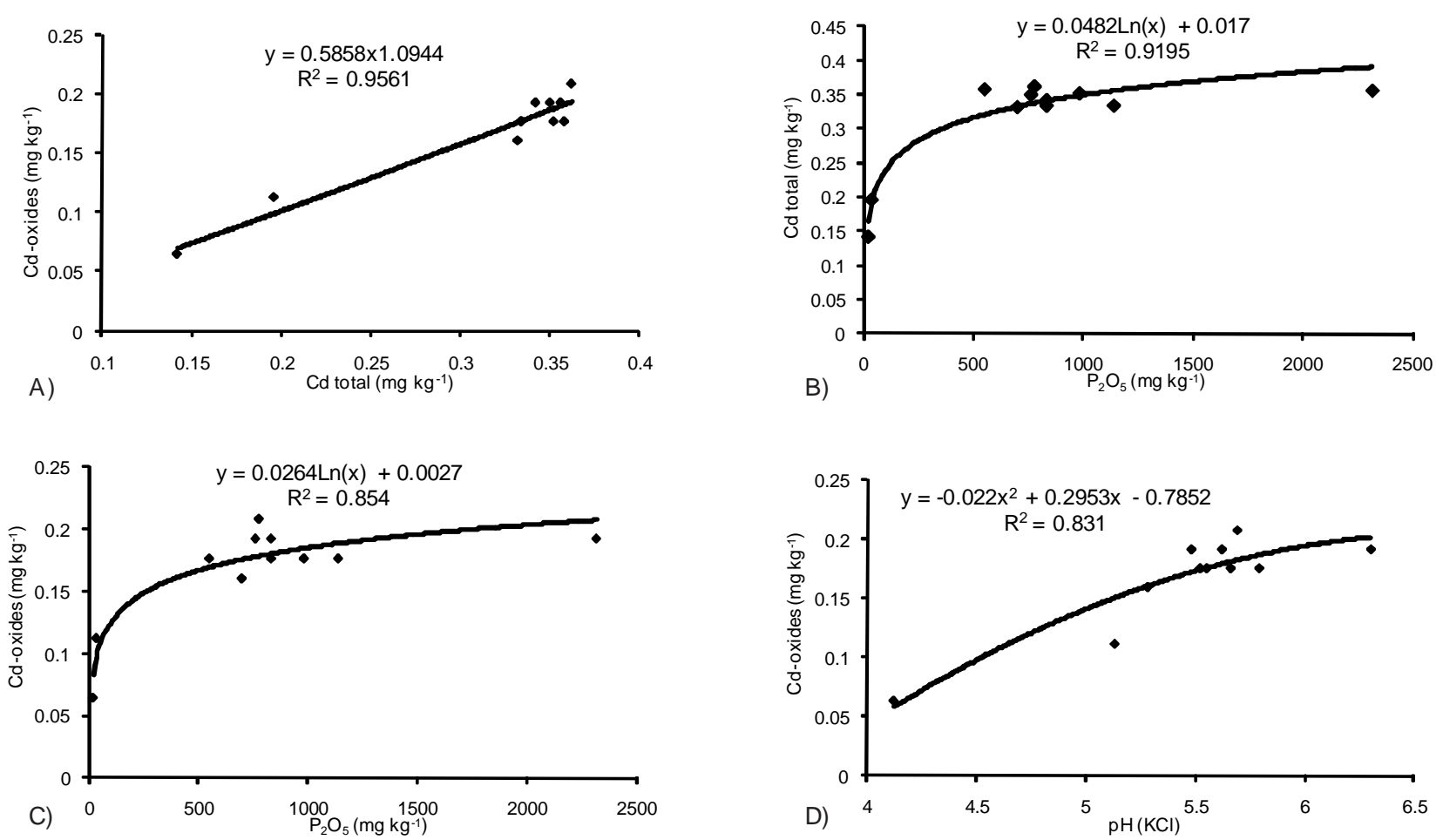

Figure 4 - Total or fractions cadmium concentration in the soil as a function of parameters for the surface horizon - SH. (Regression analysis: $p<0.05)$.

lowing order of compatibility and intensity of the adsorption of trace metals by active sites of humic acids (when in low concentration): $\mathrm{Cu}>\mathrm{Zn}>\mathrm{Cd}$.

In $\mathrm{SH}$, the total-Cd and Cd-oxide concentrations present a high regression coefficient (Figure 4A). In agreement with the equation of the dependence, the Cd-oxide fraction is around $58 \%$ of the total Cd concentration. The retention as Cd-oxide fraction is also $\mathrm{pH}$ dependent (Figure 4D). The logarithmic relationships between the total $\mathrm{Cd}(4 \mathrm{~B})$ and $\mathrm{Cd}$ oxides (4C) with the $\mathrm{P}_{2} \mathrm{O}_{5}$ values reveal a synergistic effect of $\mathrm{P}_{2} \mathrm{O}_{5}$ on $\mathrm{Cd}$ retention in soil at the surface horizon. Therefore, the highest control of the $\mathrm{Cd}$ concentration and distribution in cultivated soil is associated with the $\mathrm{P}_{2} \mathrm{O}_{5}$ presences. The behavior was not identified in the $\mathrm{DH}^{2}$ horizon $\left(\mathrm{R}^{2}>\right.$ 0.75). Moreover, when considering the use of organic or mineral phosphate fertilizers, the accumulation of $\mathrm{Cd}$ in the top horizon of soil may increase.

\section{Conclusions}

The Cd distribution in cultivated soils followed the sequence: bounded to $\mathrm{Fe}$ and $\mathrm{Mn}$ oxides + phosphates $>$ exchangeable $>$ bounded to O.M. $\approx$ residual fraction. In the surface horizon, $\mathrm{Cd}$ concentration was highly correlated to available $\mathrm{P}_{2} \mathrm{O}_{5}$ and soil $\mathrm{pH}$. In the deep horizon (under the plowed horizon), O.M. and CEC are the most important properties to explain the distribution of $\mathrm{Cd}$ into the soil. Cadmium concentration associated with total, exchangeable and bounded to oxides fractions were relatively lower than in the surface horizon.

\section{References}

Abou-Zied, M.M.A. 2007. Reducing bioavailability of some heavy metals in a contaminated soil using phosphate amendments. Egyptian Journal of Soil Science 47: 9-22.

Baize, D. 2000a. Handbook for pedological analysis: choice, use, presentation, interpretation. INRA, Paris, France. (in French).

Baize, D. 2000b. The level of heavy metals in the soil: results of the ASPITET programme (the contribution of pedological stratification to the interpretation of trace element contents). Courrier de l'Environnement 39: 39-54. Available at: http:// www.inra.fr/dpenv/baizec39.htm. [Accessed Apr. 14, 2007]. (in French, with abstract in English).

Bertoncini, E.I.; Mattiazzo, M.E. 1999. Leaching of heavy metals in soils amended with sewage sludge. Revista Brasileira de Ciência do Solo 23: 737-744. (in Portuguese, with abstract in English).

Berwanger, A.L.; Ceretta, C.A.; Santos, D.R. 2008. Soil phosphorus alteration by pig slurry application. Revista Brasileira de Ciência do Solo 32: 2525-2532. (in Portuguese, with abstract in English).

Bizarro, V.G.; Meurer, E.J.; Tatsch, F.R.P. 2008. Cadmium contents of phosphate fertilizers marketed in Brazil. Ciência Rural 38: 247-250. (in Portuguese, with abstract in English).

Campbell, C.G.; Garrido, F.; Illera, V.; García-González, M.T. 2006. Transport of $\mathrm{Cd}, \mathrm{Cu}$ and $\mathrm{Pb}$ in an acid soil amended with phosphogypsum, sugar foam and phosphoric rock. Applied Geochemistry 21: 1030-1043.

Campos, M.L.C.; Silva, F.N.; Furtini Neto, A.E.; Guilherme, L.R.G.; Marques, J.J.; Antunes, A.S. 2005. Determination of cadmium, copper, chromium, nickel, lead and zinc in rock phosphates. Pesquisa Agropecuária Brasileira 40: 361-367. (in Portuguese, with abstract in English).

Curmi, P; Widiatmaka, S. 1995. Soil distribution model in the loamy cover of the Armorican Massif (France): role and origin of hydromorphy. Available at: natres.psu.ac.th/Link/ SoilCongress/bdd/symp30/404-t.pdf. [Accessed Mar. 21, 2004]. 
Frentiu, T.; Ponta, M.; Levei, E.; Gheorghiu, E.; Kasler, I.; Cordos, E.A. 2008. Validation of the Tessier scheme for speciation of metals in soil using the Bland and Altman test. Chemical Papers 62: 114-122.

Gomes, P.C.; Fontes, M.P.F.; Costa, L.M.; Mendonça, E.S. 1997. Fractional extraction of heavy metals from Redyellow Latosol. Revista Brasileira de Ciência do Solo 21: 543-551. (in Portuguese, with abstract in English).

Hountin, J.A.; Couillard, D.; Karam, A. 1997. Soil carbon, nitrogen and phosphorus contents in maize plots after 14 years of pig slurry applications. Journal of Agricultural Science 129: 187191.

Korte, N.E.; Skopp, J.; Fuller, W.H.; Niebla, E.E. ; Alesii, B.A. 1976. Trace element movement in soils: influence of soil physical and chemical properties. Soil Science 122: 350-359.

Levasseur, P. 2002. Detailed chemical composition of food and pig manure. Techni 25: 19-25. (in French).

Matos, A.T.; Fontes, M.P.F.; Jordão, C.P.; Costa, L.M. 1996. Heavy metals mobility and retention forms in a Brazilian Oxisol. Revista Brasileira de Ciência do Solo 20: 379-386. (in Portuguese, with abstract in English).

Melo, E.E.C.; Nascimento, C.W.A.; Santos, A.C.Q.; Silva, A.S. 2008. Availability and fractionation of $\mathrm{Cd}, \mathrm{Pb}, \mathrm{Cu}, \mathrm{AND} \mathrm{Zn}$ in soil as a function of incubation time and $\mathrm{pH}$. Ciência e Agrotecnologia 32: 776-784. (in Portuguese, with abstract in English).

Mendes, A.M.S.; Duda, G.P.; Nascimento, C.W.A.; Silva, M.O. 2006. Bioavailability of cadmium and lead in a soil amended with phosphorus fertilizers. Scientia Agricola 63: 328-332.

Mortvedt, J.J.; Osborn, G. 1982. Studies on the chemical form of Cadmium contaminants in phosphate fertilizers. Soil Science 134: 185-192.
Mulla, D.J.; Page, A.L.; Ganje, T.J. 1980. Cadmium accumulations and bioavailability in soils from long-term phosphorus fertilization. Journal of Environmental Quality 9: 408-412.

Pierangeli, M.A.P.; Guilherme, L.R.G.; Curi, N.; Anderson, S.J.; Lima, J.M. 2004. Cadmium, copper, and lead adsorption and desorption in Oxisol samples pre-treated with phophorus. Revista Brasileira de Ciência do Solo 28: 377-384. (in Portuguese, with abstract in English).

Rao, C.R.M.; Sahuquillo, A.; Lopez Sanchez, J.F. 2008. A review of the different methods applied in environmental geochemistry for single and sequencial extraction of trace elements in soils and related materials. Water Air Soil Pollution 189: 291-333.

Raven, K.P.; Loeppert, R.H. 1997. Trace element composition of fertilizers and soil amendments. Journal of Environmental Quality 26: 551-557.

Reuss, J.O.; Dooley, H.L.; Griffis, W. 1978. Uptake of cadmium from phosphate fertilizers by peas, radishes and lettuce. Journal of Environmental Quality 7: 128-133.

Silveira, M.L.; Alleoni, L.R.F.; Chang, A. 2008. Soil amendments and heavy metal retention and distribution in Oxisols treated with biosolids. Revista Brasileira de Ciência do Solo 32: 10871098. (in Portuguese, with abstract in English).

Tessier, A.; Campbell, P.G.C.; Bisson, M. 1979. Sequential extraction procedure for the speciation of particulate trace metals. Analytical Chemistry 51: 844-851.

Received May 05, 2009

Accepted April 28, 2010 